\title{
Mathematical model creation for cancer chemo-immunotherapy ${ }^{1}$
}

\author{
Lisette de Pillis ${ }^{\mathrm{a}}, \mathrm{K}$. Renee Fister ${ }^{\mathrm{b}} *$, Weiqing Gu ${ }^{\mathrm{a}}$, Craig Collins ${ }^{\mathrm{c}}$, Michael Daub ${ }^{\mathrm{d}}$, \\ David Gross ${ }^{\mathrm{e}}$, James Moore ${ }^{\mathrm{e}}$ and Benjamin Preskill ${ }^{\mathrm{e}}$ \\ ${ }^{a}$ Department of Mathematics, Harvey Mudd College, Claremont, CA, USA; ${ }^{b}$ Department of \\ Mathematics, Murray State University, Murray, KY, USA; ${ }^{c}$ Murray State University, Murray, KY, \\ USA; ${ }^{d}$ Williams College, Williamstown, MA, USA; ${ }^{e}$ Harvey Mudd College, Claremont, CA, USA
}

(Received 23 February 2008; final version received 13 May 2008)

\begin{abstract}
One of the most challenging tasks in constructing a mathematical model of cancer treatment is the calculation of biological parameters from empirical data. This task becomes increasingly difficult if a model involves several cell populations and treatment modalities. A sophisticated model constructed by de Pillis et al., Mixed immunotherapy and chemotherapy of tumours: Modelling, applications and biological interpretations, J. Theor. Biol. 238 (2006), pp. 841-862; involves tumour cells, specific and non-specific immune cells (natural killer (NK) cells, $\mathrm{CD}^{+} \mathrm{T}$ cells and other lymphocytes) and employs chemotherapy and two types of immunotherapy (IL-2 supplementation and CD8 ${ }^{+} \mathrm{T}$-cell infusion) as treatment modalities. Despite the overall success of the aforementioned model, the problem of illustrating the effects of IL-2 on a growing tumour remains open. In this paper, we update the model of de Pillis et al. and then carefully identify appropriate values for the parameters of the new model according to recent empirical data. We determine new NK and tumour antigen-activated $\mathrm{CD}^{+}{ }^{+}$-cell count equilibrium values; we complete IL-2 dynamics; and we modify the model in de Pillis et al. to allow for endogenous IL-2 production, IL-2-stimulated NK cell proliferation and IL-2-dependent $\mathrm{CD}^{+} \mathrm{T}$-cell self-regulations. Finally, we show that the potential patient-specific efficacy of immunotherapy may be dependent on experimentally determinable parameters.
\end{abstract}

Keywords: immune system model; cancer model; parameter estimation; mixedimmuno-chemo-therapy; immunotherapy; chemotherapy

AMS Subject Classification: 34A34; 46N10; 46N60

\section{Introduction}

The role of the immune system in the elimination of cancerous tissue is not fully understood. By constructing models of tumour-immune interaction founded on empirical data, it may be possible to enhance our understanding of the effects of immune modulation. Several papers have examined mathematical models of tumour-immune interactions in depth, including [2,3,7,8,10-13,24,27,29,34,36,38] to name a few. As explained in de Pillis et al. [12], the immune component is fundamental to understanding the growth and decay of a tumour, and if immunotherapy is to be used effectively in a clinical setting, its dynamic interactions with chemotherapy and the tumour itself must be understood.

\footnotetext{
*Corresponding author. Email: renee.fister@murraystate.edu
} 
In particular, the dynamics and properties of both IL-2 and tumour antigen-activated $\mathrm{CD} 8^{+} \mathrm{T}$ cells are continuing to be explored [32,41]. Indeed, only recently have techniques been developed to capture T-cell kinetics with detailed resolution [4]. Consequently, mathematical models of immune-tumour interactions must undergo updates with the latest research. As a more thorough understanding of the molecular processes is obtained, the mechanisms, rates and magnitudes of the interactions are revised appropriately.

In de Pillis et al. [12], the authors model tumour growth in terms of a total cell count by including the influence of several immune cell effector subpopulations, namely tumour antigen-activated $\mathrm{CD}^{+} \mathrm{T}$ cells, natural killer (NK) cells and total circulating lymphocytes, in addition to the concentrations of IL-2 and chemotherapy drug in the bloodstream. This approach expands upon other models such as those investigated by Kirschner and Panetta [24], who considered a model based upon a total tumour cell population, an effector cell population and the concentration of IL-2 within the tumour compartment.

The model of de Pillis et al. [12] incorporates four types of action: natural growth, natural decay, mediated death and recruitment. Each term represents a population growing by reproduction, dying due to natural elimination, being killed by another population or drug or being recruited through a chain of immune reactions consequent to the presence of a cancer cell. Every term in the system of ordinary differential equations (ODEs) from the de Pillis et al. [12] model represents a single action. The authors also include the following assumptions:

(1) the tumour grows logistically in the absence of growth-inhibiting factors;

(2) endogenous IL-2 production is not included; and

(3) the specific action of all lymphocytes beyond activated $\mathrm{CD} 8^{+} \mathrm{T}$ cells and NK cells can be neglected.

The model we present similarly tracks the three immune populations, one tumour population and plasma concentrations of chemotherapy drug and IL-2. However, the action of immune cell subpopulations and chemicals in circulation (e.g. IL-2, chemotherapy drugs) necessarily depend on local concentration, not absolute number. We therefore elect to measure all state variables except the tumour cell count in terms of blood concentrations, which we assume are constant throughout the bloodstream. Furthermore, we investigate the kinetics of IL-2 and immune cell subpopulations, include endogenous IL-2 production and consider several biological IL-2 interactions, as discussed in Abbas et al. [1]. We also update the NK cell dynamics to allow for IL-2-stimulated NK cell proliferation, as indicated in Abbas et al. ([1]; p. 265). Although IL-2 does not bind as strongly to NK cells as it does to CD8 ${ }^{+} \mathrm{T}$ cells, due to different IL-2 receptor subtypes, because of the super-physiological levels of IL-2 present during exogenous supplementation, the NK-IL-2 interaction changes the resulting dynamics [1]. Moreover, Abbas et al. [1] make clear that all types of T cells produce IL-2. If the model is to be applicable in the absence of IL-2 supplementation, baseline endogenous IL-2 production must be taken into account. Indeed, in untreated cancer patients, plasma IL-2 levels can reach the mid-saturation point for IL-2-stimulated $\mathrm{CD} 8^{+} \mathrm{T}$-cell deactivation and this effect is important in modelling the kinetics of T-cell populations [1,35]. Furthermore, Abbas et al. [1] discuss the self-regulation of $\mathrm{CD}^{+} \mathrm{T}$ cells by helper $\mathrm{CD} 4^{+} \mathrm{T}$ cells, another type of lymphocyte. This interaction is complex, as it is IL-2-dependent and only occurs when $\mathrm{CD} 8{ }^{+} \mathrm{T}$ cells become large in number. We include this interaction in our expansion of the IL-2 kinetics; without it, the self-reinforcing behaviour of $\mathrm{CD} 8^{+} \mathrm{T}$ cells and IL-2 cause unphysiological behaviour in the form of unbounded $\mathrm{CD} 8^{+} \mathrm{T}$-cell production. By including the dynamic regulation of this immune cell subpopulation by IL-2, we are able to construct a model that comprises the proven efficacy of IL- 2 when combined with $\mathrm{CD} 8^{+} \mathrm{T}$-cell infusion. 


\section{The model}

In our update to the de Pillis et al. [12] model, we set out to include endogenous IL-2 production by $\mathrm{CD} 4^{+}$and $\mathrm{CD}{ }^{+} \mathrm{T}$ cells, account for IL-2-stimulated NK cell proliferation, capture IL-2 saturation with Michaelis-Menten dynamics and simplify certain parts of the model to allow for eventual optimal control analysis. We additionally altered and justified parameter values, inserted new parameters and modified state variable definitions.

Our first change was to alter the units of our state variables. Most of our sources, including Hellerstein et al. [20], Meropol et al. [30] and Dunne et al. [16], listed concentrations of immune cells as opposed to absolute quantities and we therefore found concentrations easier to work with in our model. We also stipulated that $M$ represent a specific chemotherapy drug, doxorubicin, to allow for more precise parameter determination. Thus, we define

$T(t)$, the total tumour cell population;

$N(t)$, the concentration (cells/l) of NK cells per litre of blood;

$L(t)$, the concentration (cells/l) of $\mathrm{CD} 8^{+} \mathrm{T}$-cells per litre of blood;

$C(t)$, the concentration (cells/l) of lymphocytes per litre of blood, not including NK cells and $\mathrm{CD}^{+} \mathrm{T}$-cells;

$M(t)$, the concentration $(\mathrm{mg} / \mathrm{l})$ of chemotherapy drug per litre of blood;

$I(t)$, the concentration (IU/l) of IL-2 per litre of blood;

$v_{L}(t)$, the number of tumour-activated $\mathrm{CD} 8^{+} \mathrm{T}$ cells injected per day per litre of blood volume (in cells/l per day);

$v_{M}(t)$, the amount of doxorubicin injected per day per litre of body volume (in $\mathrm{mg} / \mathrm{l}$ per day); and

$v_{I}(t)$, the amount of IL-2 injected per day per litre of body volume (in IU/l per day).

The ODEs of our model are stated below. See Table 1 for an explanation of the terms. For a more in-depth justification of the terms taken from the their model, see de Pillis et al. [12]:

$$
\begin{gathered}
\frac{\mathrm{d} T}{\mathrm{~d} t}=a T(1-b T)-c N T-D T-K_{T}\left(1-e^{-\delta_{T} M}\right) T \\
\frac{\mathrm{d} N}{\mathrm{~d} t}=f\left(\frac{e}{f} C-N\right)-p N T+\frac{p_{N} N I}{g_{N}+I}-K_{N}\left(1-e^{-\delta_{N} M}\right) N \\
\frac{\mathrm{d} L}{\mathrm{~d} t}=\frac{\theta m L}{\theta+I}+j \frac{T}{k+T} L-q L T+\left(r_{1} N+r_{2} C\right) T-\frac{u L^{2} C I}{\kappa+I} \\
-K_{L}\left(1-e^{-\delta_{L} M}\right) L+\frac{p_{I} L I}{g_{I}+I}+v_{L}(t), \\
\frac{\mathrm{d} C}{\mathrm{~d} t}=\beta\left(\frac{\alpha}{\beta}-C\right)-K_{C}\left(1-e^{-\delta_{C} M}\right) C \\
\frac{\mathrm{d} M}{\mathrm{~d} t}=-\gamma M+v_{M}(t) \\
\frac{\mathrm{d} I}{\mathrm{~d} t}=-\mu_{I} I+\phi C+\frac{\omega L I}{\zeta+I}+v_{I}(t),
\end{gathered}
$$

where

$$
D=d \frac{(L / T)^{l}}{s+(L / T)^{l}} .
$$


Table 1. Equation descriptions.

\begin{tabular}{|c|c|c|c|}
\hline Equation & Term & Description & Source \\
\hline $\mathrm{d} T / \mathrm{d} t$ & $\begin{array}{l}a T(1-b T) \\
-c N T \\
-D T \\
-K_{T}\left(1-e^{-\delta_{T} M}\right) T\end{array}$ & $\begin{array}{l}\text { Logistic tumour growth } \\
\text { NK-induced tumour death } \\
\mathrm{CD} 8^{+} \mathrm{T} \text { cell-induced tumour death } \\
\text { Chemotherapy-induced tumour death }\end{array}$ & $\begin{array}{l}{[12]} \\
{[12]} \\
{[12]} \\
{[12,18]}\end{array}$ \\
\hline \multirow[t]{4}{*}{$\mathrm{d} N / \mathrm{d} t$} & $e C$ & $\begin{array}{l}\text { Production of NK cells from circulating } \\
\text { lymphocytes }\end{array}$ & [12] \\
\hline & $-f N$ & NK turnover & [12] \\
\hline & $-p N T$ & $\begin{array}{l}\text { NK death by exhaustion of tumour-killing } \\
\text { resources }\end{array}$ & {$[12]$} \\
\hline & $\begin{array}{l}\left(p_{N} N I / g_{N}+I\right) \\
-K_{N}\left(1-e^{\delta_{N} M}\right) N\end{array}$ & $\begin{array}{l}\text { Stimulatory effect of IL- } 2 \text { on NK cells } \\
\text { Death of NK cells due to medicine toxicity }\end{array}$ & $\begin{array}{l}{[12]} \\
{[12,18]}\end{array}$ \\
\hline \multirow[t]{7}{*}{$\mathrm{d} L / \mathrm{d} t$} & $\begin{array}{l}(-m \theta L / \theta+I) \\
-q L T\end{array}$ & $\begin{array}{l}\mathrm{CD} 8^{+} \mathrm{T} \text {-cell turnover } \\
\mathrm{CD} 8^{+} \mathrm{T} \text {-cell death by exhaustion of tumour-killing } \\
\text { resources }\end{array}$ & $\begin{array}{l}{[1,12]} \\
{[12,27]}\end{array}$ \\
\hline & $r_{1} N T$ & $\begin{array}{l}\mathrm{CD} 8^{+} \mathrm{T} \text {-cell stimulation by NK-lysed tumour cell } \\
\text { debris }\end{array}$ & {$[12]$} \\
\hline & $r_{2} C T$ & $\begin{array}{l}\text { Activation of native } \mathrm{CD} 8^{+} \mathrm{T} \text { cells in the } \\
\text { general lymphocyte population }\end{array}$ & {$[12]$} \\
\hline & $\left(p_{I} L I / g_{I}+I\right)$ & Stimulator effect of IL- 2 on $\mathrm{CD} 8^{+} \mathrm{T}$ cells & {$[12,24]$} \\
\hline & $\left(-u L^{2} C I / \kappa+I\right)$ & $\begin{array}{l}\text { Breakdown of surplus } \mathrm{CD} 8^{+} \mathrm{T} \text { cells In the } \\
\text { presence of IL-2 }\end{array}$ & {$[1,12]$} \\
\hline & $(j T L / k+T)$ & $\begin{array}{l}\mathrm{CD} 8^{+} \mathrm{T} \text {-cell stimulation by } \mathrm{CD} 8^{+} \mathrm{T} \text { cell-lysed } \\
\text { tumour cell debris }\end{array}$ & [27] \\
\hline & $-K_{L}\left(1-e^{-\delta_{L} M}\right) L$ & Death of $\mathrm{CD} 8^{+} \mathrm{T}$ cells due to medicine toxicity & {$[12,18]$} \\
\hline $\mathrm{d} C / \mathrm{d} t$ & $\begin{array}{l}\alpha \\
-\beta C \\
-K_{C}\left(1-e^{-\delta_{C} M}\right) C\end{array}$ & $\begin{array}{l}\text { Lymphocyte synthesis in bone marrow } \\
\text { Lymphocyte turnover } \\
\text { Death of lymphocytes due to medicine toxicity }\end{array}$ & $\begin{array}{l}{[12]} \\
{[12]} \\
{[12,18]}\end{array}$ \\
\hline \multirow[t]{2}{*}{$\begin{array}{l}\mathrm{d} M / \mathrm{d} t \\
\mathrm{~d} I / \mathrm{d} t\end{array}$} & $\begin{array}{l}-\gamma M \\
-\mu_{I} I \\
\phi C\end{array}$ & $\begin{array}{l}\text { Excretion and elimination of medicine toxicity } \\
\text { IL- } 2 \text { turnover } \\
\text { Production of IL- } 2 \text { due to naive } \mathrm{CD} 8^{+} \mathrm{T} \text { cells and } \\
\mathrm{CD} 4^{+} \mathrm{T} \text { cells }\end{array}$ & $\begin{array}{l}{[12]} \\
{[12]} \\
{[1]}\end{array}$ \\
\hline & $(\omega L I / \zeta+I)$ & Production of Il-2 from activated CD ${ }^{+} \mathrm{T}$ cells & [24] \\
\hline
\end{tabular}

In Equation (1), the tumour kinetics have been left largely unchanged in form. Our only modification involved adding a coefficient $\delta_{T}$ on $M$ in the exponential kill term. This allows us more accurately to fit the model to data for doxorubicin and, in particular, avoids improper use of units.

In Equation (2), the NK equation has undergone two important changes. The recruitment term $g T^{2} N /\left(h+T^{2}\right)$ from the de Pillis et al. [12] model has been removed due to its observed insignificance within the context of the model, as evidenced by computer simulations and due to the additional complexity of the dynamics it introduces. We have added an IL-2-induced NK cell proliferation term, $p_{N} N I /\left(g_{N}+I\right)$. NK cells express the IL-2R $\beta_{\gamma_{c}}$ IL-2 receptor and IL-2 binding stimulates NK cell proliferation [1]. Although, the enzyme dissociation constant $k_{\mathrm{d}}$ for this binding is sufficiently large that IL-2-stimulated NK cell proliferation is minimal in healthy individuals, it has been shown that additional IL-2 can more than double the NK cell population [30]. Consequently, in the presence of elevated serum IL-2, as occurs in cancer or during immunotherapy, this interaction may be important $[16,35]$. The first term in the NK equation represents baseline NK cell production from circulating lymphocytes, while the second models the natural death of the cells. We have chosen to write the term with the constant $f$ as a multiplier to 
highlight the fact that the constant $e / f$, which denotes the baseline fraction of circulating lymphocytes that are NK cells, is particularly well known [1]. We added a coefficient $\delta_{N}$ on the exponential chemotherapy kill term for the same reasons we added $\delta_{T}$.

Since the turnover rate of activated $\mathrm{CD} 8^{+} \mathrm{T}$ cells is inhibited by IL-2, in Equation (3), we changed the term $-m L$ to $\theta m L /(\theta+I)$, [1]. That is, with increasing concentrations of IL-2 past a certain threshold, activated $\mathrm{CD} 8^{+} \mathrm{T}$-cell turnover is decreased. The $\theta$ in the numerator exists to preserve the original meaning of $m$. We then dramatically simplified the activated $\mathrm{CD} 8^{+} \mathrm{T}$-cell recruitment term, originally $j D^{2} T^{2} L /\left(k+D^{2} T^{2}\right)$, into the term $j T L /(k+T)$. Simulations of the de Pillis et al. [12] model indicated that the reaction-time delay introduced by the exponent on $T$ did not offer sufficiently different results to justify the increased complexity of the model. Moreover, we observed that Kuznetsov et al. [27] use an effector recruitment term of same form as our modification. A significant alteration was made to the term originally $-u N L^{2}$. From Abbas et al. [1], we noted that the deactivation of $\mathrm{CD}^{+} \mathrm{T}$ cells occurs through a pathway that requires IL-2 and the action of $\mathrm{CD} 4{ }^{+} \mathrm{T}$ cells (in circulating lymphocytes,) but not NK cells. Moreover, it occurs only at high concentrations of activated $\mathrm{CD}^{+} \mathrm{T}$ cells. Consequently, we chose to alter the term $-u N L^{2}$ by removing the dependence on $N$, adding Michaelis-Menten dynamics in IL-2 and including factors of $L^{2}$ and $C$. Because 50-60\% of the total lymphocytes in the blood are $\mathrm{CD} 4^{+} \mathrm{T}$ cells, and because we have already removed NK cells (10\% of total lymphocytes) and $\mathrm{CD}^{+} \mathrm{T}$ cells (a negligible fraction of total lymphocytes) from $C$, we can approximate the concentration of $\mathrm{CD} 4^{+} \mathrm{T}$ cells in the blood by $\eta C$, where $\eta$ is a constant absorbed into $u$ ([1]; p. 19; [39]). Finally, we also included the same coefficient addition to the exponential chemotherapy kill term, using this time $\delta_{L}$.

We did not significantly alter the circulating lymphocyte Equation (4). Our two minor modifications were to use a multiplier $\beta$ that comes from the first and second terms (which represent creation and elimination of circulating lymphocytes, respectively) to emphasize the fact that $\alpha / \beta$, the steady-state population of circulating lymphocytes is known ([1]; p. 17). We also added the exponential chemotherapy kill term in the form of $\delta_{C}$.

In Equation (5), the terms remain the same.

In Equation (6), we added a term representing the constant rate of creation of IL-2 from circulating lymphocytes (specifically $\mathrm{CD} 4^{+} \mathrm{T}$ cells and, to a lesser extent, naive $\mathrm{CD} 8^{+} \mathrm{T}$ cells) in the form of $\phi C$ and a Michaelis-Menten term in IL-2, $\omega L I /(\zeta+I)$, representing the production of IL- 2 from activated $\mathrm{CD} 8^{+} \mathrm{T}$ cells, which is inhibited in a concentrationdependent fashion by IL-2 ([1]; pp. 264-265).

\section{The parameters}

Careful determination of parameters is necessary for a complete model. We searched the available peer-reviewed literature for in vivo and in vitro studies measuring rates or steady-state quantities that factor into the model. Below, we explain our sources for each parameter and Tables 2 and 3 provide quick references for the parameter values and their significance within the model.

\subsection{Equilibrium states}

Before discussing the derivation of parameters, we determine from biological data reasonable equilibrium values for a no-tumour condition and a detectable tumour condition. These no-tumour and high-tumour state values are useful for extrapolating numerical quantities for several model parameters. Data for the detectable tumour state 
Table 2. Parameter descriptions.

\begin{tabular}{|c|c|c|}
\hline Equation & Parameter & Description \\
\hline $\mathrm{d} T / \mathrm{d} t$ & $\begin{array}{c}a \\
b \\
c \\
K_{T} \\
\delta_{T}\end{array}$ & $\begin{array}{l}\text { Growth rate of tumour } \\
\text { Inverse of carrying capacity } \\
\text { Rate of NK-induced tumour death } \\
\text { Rate of chemotherapy-induced tumour death } \\
\text { Medicine efficacy coefficient }\end{array}$ \\
\hline $\mathrm{d} N / \mathrm{d} t$ & $\begin{array}{l}e / f \\
f \\
P \\
p_{N} \\
g_{N} \\
K_{N} \\
\delta_{N}\end{array}$ & $\begin{array}{l}\text { Ratio of NK cell synthesis rate with turnover rate } \\
\text { Rate of NK cell turnover } \\
\text { Rate of NK cell death due to tumour interaction } \\
\text { Rate of IL-2 induced NK cell proliferation } \\
\text { Concentration of IL- } 2 \text { fpr half-maximal NK cell proliferation } \\
\text { Rate of NK depletion from medicine toxicity } \\
\text { Medicine toxicity coefficient }\end{array}$ \\
\hline $\mathrm{d} L / \mathrm{d} t$ & $\begin{array}{l}m \\
\theta \\
q \\
r_{1} \\
r_{2} \\
p_{I} \\
g_{I} \\
u \\
\kappa \\
j \\
k \\
K_{L} \\
\delta_{L}\end{array}$ & $\begin{array}{l}\text { Rate of activated CD8 } 8^{+} \mathrm{T} \text {-cell turnover } \\
\text { Concentration of IL- } 2 \text { to halve } \mathrm{CD} 8^{+} \mathrm{T} \text {-cell turnover } \\
\text { Rate of CD8 } 8^{+} \mathrm{T} \text {-cell death due to tumour interaction } \\
\text { Rate of NK-lysed tumour cell debris activation of CD } 8^{+} \mathrm{T} \text { cells } \\
\text { Rate of CD8 production from circulating lymphocytes } \\
\text { Rate of IL-2 induced CD8 }{ }^{+} \mathrm{T} \text {-cell activation } \\
\text { Concentration of IL- } 2 \text { for half-maximal CD8 }{ }^{+} \mathrm{T} \text {-cell activation } \\
\mathrm{CD} 8^{+} \mathrm{T} \text {-cell self-limitation feedback coefficient } \\
\text { Concentration of IL-2 to halve magnitude of CD8 }{ }^{+} \mathrm{T} \text {-cell self-regulation } \\
\text { Rate of CD8 } 8^{+} \mathrm{T}-\text {-lysed tumour cell debris activation of CD8 } 8^{+} \mathrm{T} \text { cells } \\
\text { Tumour size for half-maximal CD8 }{ }^{+} \mathrm{T}-\text {-lysed debris } \mathrm{CD} 8^{+} \mathrm{T} \text { activation } \\
\text { Rate of CD8 } 8^{+} \mathrm{T} \text { depletion from medicine toxicity } \\
\text { Medicine toxicity coefficient }\end{array}$ \\
\hline $\mathrm{d} C / \mathrm{d} t$ & $\begin{array}{l}\alpha / \beta \\
\beta \\
K_{C} \\
\delta_{C}\end{array}$ & $\begin{array}{l}\text { Ratio of rate of circulating lymphocyte production to turnover rate } \\
\text { Rate of lymphocyte turnover } \\
\text { Rate of lymphocyte depletion form medicine toxicity } \\
\text { Medicine toxicity coefficient }\end{array}$ \\
\hline $\begin{array}{l}\mathrm{d} M / \mathrm{d} t \\
\mathrm{~d} / / \mathrm{d} t\end{array}$ & $\begin{array}{l}\gamma \\
\mu_{I} \\
\omega \\
\phi \\
\zeta\end{array}$ & $\begin{array}{l}\text { Rate of excretion and elimination of doxorubicin } \\
\text { Rate of excretion and elimination of IL- } 2 \\
\text { Rate of IL-2 production from CD } 8^{+} \mathrm{T} \text { cells } \\
\text { Rate of IL-2 production from CD } 4^{+} \text {/naive CD } 8^{+} \mathrm{T} \text { cells } \\
\text { Concentration of IL-2 for half-maximal CD } 8^{+} \mathrm{T} \text {-cell IL-2 production }\end{array}$ \\
\hline D & $\begin{array}{l}d \\
l \\
s\end{array}$ & $\begin{array}{l}\text { Immune system strength coefficient } \\
\text { Immune strength scaling coefficient } \\
\text { Value of }(L / T)^{l} \text { necessary for half-maximal } \mathrm{CD} 8^{+} \mathrm{T} \text {-cell toxicity }\end{array}$ \\
\hline
\end{tabular}

can be taken, for example, from a situation in which an avascular tumour is at the size where the rates of nutrient usage and diffusion become equal.

The first equilibrium point we will call the no-tumour equilibrium, in which

$$
T=0, N=\frac{e}{f} \frac{\alpha}{\beta}=2.5 \times 10^{8}, L=2.526 \times 10^{4}, C=\frac{\alpha}{\beta}=2.25 \times 10^{9}, M=0, I=48.9273
$$

Here $T$ and $M$ are defined to be equal to zero. The algebraic expressions for $N$ and $C$ follow from setting $T=M=0$ in Equations (2) and (4), and the numerical values are derived below (see the explanations of $e / f$ in Section 3.3 and $\alpha / \beta$ in Section 3.5). Our value for $I$ is obtained from Orditura et al. [35], who note that healthy control subjects had average serum IL-2 levels of $I=2.99 \mathrm{pg} / \mathrm{ml}=48.9273 \mathrm{IU} / \mathrm{l}$, where we have converted to IU using the 
Table 3. Parameter values.

\begin{tabular}{|c|c|c|c|c|}
\hline ODE & Parameter & Value & Units & Source \\
\hline $\mathrm{d} T / \mathrm{d} t$ & $\begin{array}{c}a \\
b \\
c \\
K_{T} \\
\delta_{T}\end{array}$ & $\begin{aligned} 4.31 & \times 10^{-1} \\
1.02 & \times 10^{-9} \\
2.9077 & \times 10^{-13} \\
9 & \times 10^{-1} \\
1.8328 & \end{aligned}$ & $\begin{array}{l}\text { Day }^{-1} \\
\text { Cells }^{-1} \\
1 / \text { cells }^{-1} \text { per day } \\
\text { Day }^{-1} \\
1 / \mathrm{mg}^{-1}\end{array}$ & $\begin{array}{l}{[12,14]} \\
{[12-14]} \\
{[12-15]} \\
{[12]} \\
{[18]}\end{array}$ \\
\hline $\mathrm{d} N / \mathrm{d} t$ & $\begin{array}{c}e / f \\
f \\
p \\
p_{N} \\
g_{N} \\
K_{N} \\
\delta_{N}\end{array}$ & $\begin{array}{c}1.11 \times 10^{-1} \\
1.25 \times 10^{-2} \\
2.794 \times 10^{-13} \\
6.68 \times 10^{-2} \\
2.5036 \times 10^{5} \\
6.75 \times 10^{-2} \\
1.8328\end{array}$ & $\begin{array}{l}- \\
\text { Day }^{-1} \\
\text { Cells }^{-1} \text { per day }^{-1} \\
\text { Day }^{-1} \\
\text { IU/l }^{-1} \\
\text { Day }^{-1} \\
1 / \mathrm{mg}^{-1}\end{array}$ & $\begin{array}{l}{[1]} \\
{[6,9,19,40,48]} \\
{[1,21,28,30,33,35,39,46]} \\
{[30]} \\
{[1]} \\
{[44]} \\
{[18]}\end{array}$ \\
\hline $\mathrm{d} L / \mathrm{d} t$ & $\begin{array}{c}m \\
\theta \\
q \\
r_{1} \\
r_{2} \\
p_{I} \\
g_{I} \\
u \\
k \\
j \\
k \\
K_{L} \\
\delta_{L}\end{array}$ & $\begin{aligned} 9 & \times 10^{-3} \\
2.5036 & \times 10^{-3} \\
3.422 & \times 10^{-10} \\
2.9077 & \times 10^{-11} \\
5.8467 & \times 10^{-13} \\
2.971 & \\
2.5036 & \times 10^{3} \\
4.417 & \times 10^{-14} \\
2.5036 & \times 10^{3} \\
1.245 & \times 10^{-2} \\
2.019 & \times 10^{7} \\
4.86 & \times 10^{-2} \\
1.8328 & \end{aligned}$ & $\begin{array}{l}\text { Day } \\
\text { IU }^{-1} \\
\text { Cells }^{-1} \text { per day }^{-1} \\
\text { Cells }^{-1} \text { per day }^{-1} \\
\text { Cells }^{-1} \text { per day }^{-1} \\
\text { Day }^{-1} \\
\text { IU/l }^{-1} \\
1^{2} / \text { cells }^{-2} \text { per day }^{-1} \\
{\text { IU } / l^{-1}}^{-1} \\
\text { Day } \\
\text { Cells } \\
\text { Day }^{-1} \\
1 / \mathrm{mg}^{-1}\end{array}$ & $\begin{array}{l}{[20]} \\
{[1,41]} \\
{[25,27]} \\
{[5,21]} \\
\text { No source } \\
{[1,21,28,30,33,35,39,46]} \\
{[1]} \\
{[1,21,28,30,33,35,39,46]} \\
{[1,41]} \\
{[27]} \\
{[27]} \\
{[44]} \\
{[18]}\end{array}$ \\
\hline $\mathrm{d} C / \mathrm{d} t$ & $\begin{array}{l}\alpha / \beta \\
\beta \\
K_{C} \\
\delta_{C}\end{array}$ & $\begin{array}{r}2.25 \times 10^{-1} \\
6.3 \times 10^{-3} \\
3.4 \times 10^{-2} \\
1.8328\end{array}$ & $\begin{array}{l}\text { Cells/l-1 } \\
\text { Day }^{-1} \\
\text { Day }^{-1} \\
1 / \mathrm{mg}^{-1}\end{array}$ & $\begin{array}{l}{[1]} \\
{[9,12,17,19]} \\
{[44]} \\
{[18]}\end{array}$ \\
\hline $\begin{array}{l}\mathrm{d} M / \mathrm{d} t \\
\mathrm{~d} I / \mathrm{d} t\end{array}$ & $\begin{array}{l}\gamma \\
\mu_{I} \\
\omega \\
\phi \\
\zeta\end{array}$ & $\begin{array}{l}5.199 \times 10^{-1} \\
11.7427 \\
7.874 \times 10^{-2} \\
2.38405 \times 10^{-7} \\
2.5036 \times 10^{3}\end{array}$ & $\begin{array}{l}\text { Day }^{-1} \\
\text { Day }^{-1} \\
\text { IU/cells }^{-1} \text { per day }^{-1} \\
\text { IU/cells }^{-1} \text { per day } \\
\text { IU/l }\end{array}$ & $\begin{array}{l}{[22,47]} \\
{[26]} \\
{[1,21,28,30,33,35,39,46]} \\
{[1,21,28,30,33,35,39,46]} \\
{[1]}\end{array}$ \\
\hline$D$ & $\begin{array}{l}d \\
l \\
s\end{array}$ & $\begin{array}{l}\text { Not specified } \\
\text { Not specified } \\
\text { Not specified }\end{array}$ & $\begin{array}{l}\text { Day }^{-1} \\
- \\
1^{-l}\end{array}$ & $\begin{array}{l}{[15]} \\
{[12,13]} \\
{[12,13]}\end{array}$ \\
\hline
\end{tabular}

assumption that we have $18 \times 10^{6} \mathrm{IU}$ IL-2 per $1.1 \mathrm{mg}$ IL-2 [33]. Finally, $L$ is derived from Pittet et al. [39], who indicate that in healthy blood donors, total $\mathrm{CD} 8^{+} \mathrm{T}$ cells specific for the Melan-A gene (a tumour-associated antigen in melanoma) constitute approximately $0.0421 \%$ of total $\mathrm{CD}^{+} \mathrm{T}$ cells. The average of all healthy donor values in Table 1 of Pittet et al. and Speiser et al. [46] show that we can associate the activated CD8 ${ }^{+} \mathrm{T}$-cell population with those expressing 2B4. Since in Figure 5b of Speiser et al. approximately $10 \%$ of Melan-A specific T cells express 2B4, we see that $0.00421 \%$ of all CD8 ${ }^{+} \mathrm{T}$ cells are expected to be activated and specific for a tumour-associated antigen. Although Melan-A is not always the most heavily expressed tumour-associated-antigen even in melanoma, data from Table 2 in Lee et al. [28] suggest that other antigens will result in a similar degree of $\mathrm{CD} 8^{+} \mathrm{T}$-cell activation. This gives the equilibrium value of $L$ when combined with the value for total $\mathrm{CD}^{+} \mathrm{T}$ cells of $6 \times 10^{8}([21]$; p. 751$)$. 
The second equilibrium point, we call the large-tumour equilibrium and this is given by

$$
T=9.8039 \times 10^{8}, N=2.5 \times 10^{8}, L=5.268 \times 10^{5}, C=\frac{\alpha}{\beta}=2.25 \times 10^{9}, M=0, I=1073,
$$

We again define $M=0$ as we are not interested in the effects of chemotherapy. The algebraic expressions for $T$ and $C$ follow from the model, as in the no-tumour equilibrium. Numerical values are again derived below (see the justifications of $b$ in Section 3.2, elf in Section 3.3 and $\alpha / \beta$ in Section 3.5.) $N$ is derived from Figure 1 in Meropol et al. [30], who measure the baseline concentration of NK cells in peripheral blood of breast cancer patients. $I$ is again taken from Orditura et al. [35], who measure that serum IL-2 levels were on average $I=71.69 \mathrm{pg} / \mathrm{ml}=1173 \mathrm{IU} / \mathrm{l}$ in stage III cancer patients prior to chemotherapy. Note that we use the value for stage III patients to avoid including patients with metastatic cancer, as the model is designed to represent localized malignancy. Finally, $L$ is derived from Lee et al. [28] by averaging the percent of CD8 data in Lee's Table 2 among the first five populations, which are activated for an antigen, to arrive at an average of $0.0878 \%$ activated $\mathrm{CD} 8^{+} \mathrm{T}$ cells specific for one of the melanoma antigens Melan-A/Mart-1 and tyrosinase. Along with the total $\mathrm{CD}^{+} \mathrm{T}$-cell value above from Janeway et al. [21]; (p. 751), this gives the equilibrium value for $L$.

\section{$3.2 d \mathrm{~T} / d \mathrm{t}:$ The tumour}

$a=4.31 \times 10^{-1}$ is left unchanged from the de Pillis et al. [12] model, as the model is extraordinarily sensitive to $a$ and no data could be found supporting a different value. De Pillis et al. [12] derived the parameter from Diefenbach et al. [14].

$b=1.02 \times 10^{-9}$ is also left unchanged from the de Pillis et al. [12] model. Both de Pillis et al. [13] and de Pillis et al. [12] arrived at the same value from Diefenbach et al. [14], suggesting that this parameter is well-substantiated. Note that $1 / b=9.8039 \times 10^{8}$ is the tumour carrying capacity.

$c=2.9077 \times 10^{-13}$ is based on the approximation that for every NK cell that kills a tumour cell, one NK cell dies. We then let $c=p$, since $c$ is the rate at which NK cells kill tumour cells and $p$ is the rate at which NK cells die from the same process. Note that the value of $p$ is derived in Section 3.3. Although we lack documentation for our approximation, the near equality of $p$ and $c$ in the de Pillis et al. [12] model implies that we are not conceptually contradicting previous work. As further substantiation for our value of $c$, chromium-release assays in Dudley et al. [15] and Diefenbach et al. [14] suggest that NK cells kill tumour cells at a mass-action rate of $\approx 10^{-7}$ in vitro. This is comparable to the value $c=3.23 \times 10^{-7}$ used in de Pillis et al. [13]. However, because NK cells circulate and do not solely exist in the vicinity of the tumour, an in vitro value cannot be directly applied to a human model. Instead, we approximate (in agreement with de Pillis et al. [12]) that only 1 in $10^{6} \mathrm{NK}$ cells interacts with the tumour in vivo, which leads to the conclusion that $c$ is on the order of $10^{-13}$. The approximation is derived from estimates of $10^{8}$ cells in an average tumour and $10^{14}$ cells in the human body, so if NK cells distribute themselves evenly over all tissue, only 1 in $10^{6}$ will lie in the tumour. As our interaction assumption and order-of-magnitude derivation agree, the value of $c$ is appears reasonable.

$K_{T}=0.9$ is left unchanged from the de Pillis et al. [12] model, as we found no data supporting a different value. de Pillis et al. [12] took it originally from Ref. [37].

$\delta_{T}=1.8328$ is taken from Gardner [18]. Table 4 of Gardner lists a value of $\alpha=1.063 \mu \mathrm{M}^{-1}$ for doxorubicin acting on the primary cell line. Since our medicine kill 
Table 4. Simulation results for patient 9, patient 10. Here, $x$ represents the eradication of the tumour and $o$ denotes the survival of the tumour).

\begin{tabular}{|c|c|c|c|c|c|c|c|c|}
\hline \multirow{2}{*}{$\begin{array}{l}\text { Simulation } \\
\text { Patient number }\end{array}$} & \multicolumn{2}{|c|}{$T=\underset{\text { cells }}{1 \times 10^{6}}$} & \multicolumn{2}{|c|}{$T=\underset{\text { cells }}{1 \times 10^{7}}$} & \multicolumn{2}{|c|}{$T=\underset{\text { cells }}{1 \times 10^{8}}$} & \multicolumn{2}{|c|}{$T=\underset{\text { cells }}{1 \times 10^{9}}$} \\
\hline & 9 & 10 & 9 & 10 & 9 & 10 & 9 & 10 \\
\hline No treatment & $x$ & $x$ & $o$ & $o$ & $o$ & $o$ & $o$ & $o$ \\
\hline Chemotherapy & $x$ & $x$ & $x$ & $x$ & $x$ & $x$ & $o$ & $o$ \\
\hline Immunotherapy & $x$ & $x$ & $x$ & $o$ & $o$ & $o$ & $o$ & $o$ \\
\hline Chemo-immuno & $x$ & $x$ & $x$ & $x$ & $x$ & $o$ & $o$ & $o$ \\
\hline
\end{tabular}

term reflects the dynamics suggested in Gardner, we use Gardner's value of $a$ converted to units of $1 / \mathrm{mg}$. Taking the molar mass of doxorubicin $\mathrm{HCl}$ as $579.99 \mathrm{~g} / \mathrm{mol}$ [43], we arrive at our value for $\delta_{T}$ as follows:

$$
\begin{aligned}
\delta_{T} & =1.0631 / \mu \mathrm{mol}\left(\frac{1 \times 10^{6} \mu \mathrm{mol}}{1 \mathrm{~mol}}\right)\left(\frac{1 \mathrm{~mol}}{579.99 \mathrm{~g} \text { doxorubicin }}\right)\left(\frac{1 \mathrm{~g}}{1000 \mathrm{mg}}\right) \\
& =1.83281 / \mathrm{mg} .
\end{aligned}
$$

\section{$3.3 d \mathrm{~N} / d \mathrm{t}:$ The natural killer cells}

$e / f=1.11 \times 10^{-1}$ is equal to the ratio $N / C$ at equilibrium if we ignore the small effect of IL-2 on NK proliferation in the absence of exogenous supplementation. Since Abbas et al. ([1]; p. 19) indicate that NK cells make up approximately $10 \%$ of total circulating lymphocytes in the absence of a tumour, and the number of activated $\mathrm{CD} 8^{+} \mathrm{T}$ cells $L$ is several orders of magnitude smaller than $N$ in healthy blood donors and thus negligible (see the no-tumour equilibrium condition (8)), we can approximate $e / f=1 / 9 \approx 1.11 \times 10^{-1}$. Note that $C$ here measures the number of total lymphocytes that are neither activated $\mathrm{CD} 8^{+} \mathrm{T}$ cells nor NK cells.

$f=1.25 \times 10^{-2}$ was found by metabolic scaling. The average mass of an adult human male is $77 \mathrm{~kg}$ and the average mass for an adult male rhesus monkey is $11.9 \mathrm{~kg}[40,48]$. From Gillooly et al. [19], we see that mass-specific metabolic rate $B$ scales as:

$$
B / M \propto M^{-1 / 4},
$$

where $M$ is mass. We do recognize that there is consideration for different scaling behaviour depending on the location of cells in the body. However, Gillooly et al. [19] explain that when the masses of two organisms differ significantly, the scaling law is obeyed with good

\begin{tabular}{lcc}
\hline Animal & Mass $(\mathrm{kg})$ & $M^{-1 / 4}\left(\mathrm{~kg}^{-1 / 4}\right)$ \\
\hline Human & 77 & 0.3376 \\
Rhesus monkey & 11.9 & 0.5384 \\
\hline
\end{tabular}

precision. We have

We assume that $f$, corresponding to the turnover rate of NK cells, is proportional to mass-specific metabolic rate. Since we have $f_{\text {monkey }}=2 \times 10^{-2}$ for a rhesus monkey taken from de Boer et al. [9], we have:

$$
f=\Gamma(B / M)=\Gamma^{\prime} M^{-1 / 4},
$$


where $\Gamma$ and $\Gamma^{\prime}$ are constants, and the second equality follows from the aforementioned proportionality. Now:

$$
\Gamma^{\prime}=\frac{f_{\text {monkey }}}{M_{\text {monkey }}^{-1 / 4}}=0.0371,
$$

from the data for the rhesus monkey. Using this to find $f$ for a human, we have:

$$
f=\Gamma^{\prime} M_{\text {human }}^{-1 / 4}=1.25 \times 10^{-2},
$$

for an average human.

$p=2.794 \times 10^{-13}$ is obtained by considering that at the large-tumour equilibrium and in the absence of medicine, we have

$$
0=\frac{\mathrm{d} N}{\mathrm{~d} t}=f\left(\frac{e}{f} C-N\right)-p N T+\frac{p_{N} N I}{g_{N}+I},
$$

The term $((e / f) C-N)$ is zero because we make the assumption in this case that at equilibrium $e / f=N / C$. We then have:

$$
p=\frac{p_{N} I}{T\left(g_{N}+I\right)} .
$$

Using the values of $p_{N}$ and $g_{N}$ calculated below and the equilibrium values from Equation (9), we arrive at our value for $p$.

$g_{N}=2.5036 \times 10^{5}$ is derived from Abbas et al. ([1]; p. 265), where we see the concentration of IL-2 required for half-maximal binding of cells expressing the IL-2R $\beta \gamma_{c}$ receptor complex is $10^{-9} \mathrm{~mol} / \mathrm{l}$, as opposed to $10^{-11} \mathrm{~mol} / \mathrm{l}$ for cells expressing the IL-2R $\alpha \beta \gamma_{\mathrm{c}}$ receptor complex. Since NK cells express the former receptor exclusively, we arrive at our value for $g_{N}$ by using $15,300 \mathrm{Da}(15,300 \mathrm{~g} / \mathrm{mol})$ as the molecular mass of IL-2 and employing the conversion factor of $18 \times 10^{6}$ IU IL-2 per $1.1 \mathrm{mg}$ IL-2 to convert molar concentration to IU/1 [1,33]. We therefore have:

$$
g_{N}=\left(\frac{1 \times 10^{-9} \mathrm{~mol}}{11}\right)\left(\frac{15,300 \mathrm{~g}}{1 \mathrm{~mol}}\right)\left(\frac{1000 \mathrm{mg}}{1 \mathrm{~g}}\right)\left(\frac{1.8 \times 10^{7} \mathrm{IU}}{1.1 \mathrm{mg}}\right)=2.5036 \mathrm{IU} / 1 .
$$

$p_{N}=6.68 \times 10^{-2}$ is taken from data in Meropol et al. [30] measuring NK cell proliferation in response to IL-2 in the absence of a tumour. Note that $p_{N}$ measures how effectively NK cells are stimulated by IL- 2 and is independent of the presence of a tumour. We assume that the peak NK cell count $N=2.3 \times 10^{9}$ in Figure 3 of Meropol et al. [30] corresponds to the equilibrium value of $N$ subject to the peak value of IL-2 $I=200 \mathrm{pmol} / \mathrm{l}=5.0073 \times 10^{4} \mathrm{IU}$ from Figure 4 of Meropol et al. [30]. Assuming now that we have exogenous IL-2 supplementation, we allow for a non-negligible effect of IL-2 on NK cell proliferation. Thus, the term $((e / f) C-N)$ in $(2)$ is now assumed to be non-zero. Additionally, we assume $p N T$ is small, as in the absence of a tumour, and we have:

$$
0=\frac{\mathrm{d} N}{\mathrm{~d} t}=f\left(\frac{e}{f} C-N\right)+\frac{p_{N} N I}{g_{N}+1}
$$

which gives

$$
p_{N}=\frac{f\left(N-\frac{e}{f} C\right)\left(g_{N}+I\right)}{N I}
$$


We then use $C=2.25 \times 10^{9}$ as our equilibrium circulating lymphocyte concentration from the no-tumour equilibrium (8) and the values of $N$ and $I$ above to calculate $p_{N}$.

$K_{N}=6.75 \times 10^{-2}$ is derived from linearly scaling $K_{C}$ by the ratio of cell metabolic rates. More precisely, we let:

$$
K_{N}=\frac{f}{\beta} K_{C}
$$

From the observation in de Pillis et al. [12], we know that cells with a faster metabolic rate are killed more effectively by doxorubicin. Lacking evidence to the contrary, we assume this relationship is linear.

$\delta_{N}=\delta_{T}=1.8328$ by assuming that similar concentrations of doxorubicin are necessary to affect all cell types, even though the drug has differential efficacy depending on the metabolic rate of the cell.

\section{$3.4 d \mathrm{~L} / d \mathrm{t}:$ The $C D 8^{+}$T cells}

$m=9 \times 10^{-3}$ is from Hellerstein et al. [20], who put the half-life of $\mathrm{CD}^{+}$cells at 77 days in healthy donors. Assuming exponential decay and using $m=m \times t_{1 / 2}=\ln 2$, we arrive at our value for $m$.

$\theta=2.5036 \times 10^{3}$ was derived from Abbas et al. [1] based on the existence of the IL-2R $\alpha \beta \gamma_{\mathrm{c}}$ receptor on $\mathrm{CD}^{+} \mathrm{T}$ cells. Consequently, the concentration needed for half-maximal IL-2 binding is $10^{-11} \mathrm{~mol} / \mathrm{l}$, which works out to $2.5036 \times 10^{3} \mathrm{IU} / \mathrm{l}$, as in the derivation of $g_{N}$.

$q=3.422 \times 10^{-10}$ was taken from Kuznetsov et al. [27] as we are unable to find kinetics data on activated $\mathrm{CD} 8^{+} \mathrm{T}$-cell-tumour interaction. It must be recognized that Kuznetsov et al. [27] used mouse data and modelled the effector cell population, as opposed to the $\mathrm{CD} 8^{+} \mathrm{T}$-cell population, but we found no other data suggesting values for $q, j$ and $k$. In support of our value of $q$ however, we expect $q$ to be approximately three orders of magnitude less than $p$, due to the relative magnitudes of $L$ and $N$ (based on the two sets of equilibrium values (8), (9)) and this is indeed the case.

$r_{1}=100 \times c=2.9077 \times 10^{-11}$ is derived from the approximation that each lysed tumour cell, through antigen-presenting pathways, can activate 50 naive $\mathrm{CD}^{+} \mathrm{T}$ cells per day. This figure is adapted from Avigan et al. [5], who note that a single dendritic cell can stimulate 100-3000 T cells over the course of its life in the presence of an antigen. Rudel et al. [42] indicate that the turnover rate of at least one type of dendritic cell is 10 days, suggesting that a dendritic cell may stimulate 10-300 T cells per day. We choose the figure of $100 \mathrm{~T}$ cells/l per day, since neither an average nor a standard deviation is given in Avigan et al. [5]. Even at this level, the parameter $r_{1}$ turns out not to have an enormous impact relative to the other model parameters.

$r_{2}=5.8467 \times 10^{-13}$ is chosen to obtain a model consistent with expectations, much in the same way as de Pillis et al. chose the value of $r_{2}$ in their model. There are very limited data on $\mathrm{CD} 4{ }^{+} \mathrm{T}$-cell (the primary constituent of $C$ ) activation of $\mathrm{CD} 8^{+} \mathrm{T}$ cells, and we found no research measuring the kinetics.

$u=4.417 \times 10^{-14}$ is derived by solving a system of equations designed to produce reasonable equilibrium behaviour. The two equilibrium conditions (8) and (9) combined with the known $\mathrm{d} L / \mathrm{d} t$ parameter values in this section fix all variables in $\mathrm{d} L / \mathrm{d} t$ other than $p_{I}$ and $u$. We thus set $\mathrm{d} L / \mathrm{d} t=0$, insert the two sets of equilibrium values into Equation (3) along with the values of all parameters except for $u$ and $p_{I}$ and thereby obtain two equations in $u$ and $p_{I}$. Solving these equations numerically gives us our solution. 
$\kappa=2.5036 \times 10^{3}$ was obtained from Abbas et al. [1] in the same way as $\theta$. Refaeli et al. [41] observe that upon removal of the $\alpha \mathrm{IL}-2$ receptor chain, $\mathrm{CD} 8^{+} \mathrm{T}$ cells fail to self-regulate. This affirms that $\kappa$ should correspond to the disassociation constant for the IL- $2 \mathrm{R} \alpha \beta \gamma_{\mathrm{c}}$ receptor.

$p_{I}=2.971$ is taken from the solution to the system in $u$ and $p_{I}$ above.

$g_{I}=2.5036 \times 10^{3}$ is derived from Abbas et al. [1] in the same way as $\theta$ and $\kappa$.

$j=1.245 \times 10^{-1}$ is taken from Kuznetsov et al. [27] for lack of data in humans.

$k=2.019 \times 10^{7}$ is taken from Kuznetsov et al. [27] for lack of data in humans.

$k_{L}=0.0486$ is derived from the same linear metabolic scaling used to derive $K_{N}$ from

$K_{C}$. Thus, we let:

$$
K_{L}=\frac{m}{\beta} K_{C}
$$

and thereby find $K_{L}$.

$\delta_{L}=1.8328$ is approximated under the assumption of equality with $\delta_{T}$ as in the derivation of $\delta_{N}$.

\section{$3.5 d \mathrm{C} / \mathrm{dt}$ : The circulating lymphocytes}

$\alpha / \beta=C=2.5 \times 10^{9}$ follows as under normal healthy conditions, $\mathrm{d} C / \mathrm{d} t=0$ and no chemotherapy medicine is present. We take the average value of circulating lymphocytes to be $2.5 \times 10^{9}$ cells/l ([1]; p. 17). However, we factor out both NK, which cells make up $10 \%$ of circulating lymphocytes in a healthy human, and activated $\mathrm{CD} 8^{+} \mathrm{T}$ cells, which constitute a negligible fraction of circulating lymphocytes as noted in the derivation of $\mathrm{f}$, due to their plastic nature [1]. Consequently, we have:

$$
\frac{\alpha}{\beta}=\left(2.5 \times 10^{9}\right)(0.9)=2.25 \times 10^{9}
$$

$\beta=6.3 \times 10^{-3}$ is obtained by taking the $1 \%$ turnover rate of $\mathrm{CD}^{+} \mathrm{T}$ cells (which are the primary constituent of the population measured by $C$ ) in rhesus monkeys cited in Boer et al. [9] and applying metabolic scaling. (See the explanation of $f$.)

$K_{C}=0.034$ is derived from the observation that the median white blood cell count after doxorubicin treatment for several weeks using exactly our treatment protocol was $1.6 \times 10^{3}$ cells $/ \mu l=1.6 \times 10^{9}$ cells $/ 1$ [44]. If we assume that in these patients we still have the relationship $N=(1 / 10) C$, then this white blood cell count (which includes all circulating lymphocytes) should correspond to $C=(9 / 10)\left(1.6 \times 10^{9}\right)=1.44 \times 10^{9}$. By repeatedly running ODE simulations of the $\mathrm{d} C / \mathrm{d} t$ ODE, which is independent of all but $M$, with the no-tumour equilibrium data (8) and chemotherapy turned on, we found that $K_{C}=0.155$ produced a nadir value of $C=1.447 \times 10^{9}$ as desired.

$\delta_{C}=1.8328$ is approximated under the assumption of equality with $\delta_{T}$.

\section{6 $d \mathrm{M} / d \mathrm{t}$ : The chemotherapy}

$\gamma=\ln 2 / 1.3332$ days $=0.5199$ is derived from the assumption of exponential decay. The tissue (as opposed to blood, from which the drug is eliminated rapidly) elimination half-life of doxorubicin, the chemotherapy medicine on which the de Pillis et al. [12] model is based, is approximately $32 \mathrm{~h}$ or 1.3332 days $[22,47]$. 


\section{$3.7 d \mathrm{I} / d \mathrm{t}:$ The $I L-2$}

$\mu_{I}=\ln 2 / 5.90 \times 10^{-2}$ days $=11.7427$ days $^{-1}$ is again derived from assumption of exponential decay. The half-life of serum IL-2 is biphasic with a tissue elimination half-life of $t_{1 / 2}=85 \mathrm{~min}$ [26]. Our value follows after converting to days.

$\omega=7.874 \times 10^{-2}$ was found by a similar procedure to that used to find $u$. Using the equilibrium values (8), (9) and the known $\mathrm{d} I / \mathrm{d} t$ parameters, we found $\omega$ and $\phi$ by solving a system of equations generated by setting $\mathrm{d} I / \mathrm{d} t=0$ and inserting both sets of equilibrium conditions.

$\phi=2.38405 \times 10^{-7}$ was found as part of the solution to the system created to find $\omega$.

$\zeta=g_{I}=2.5036 \times 10^{3}$, as the term comprising $\zeta$ pertains to $\mathrm{CD}^{+} \mathrm{T}$-cell IL-2 synthesis induced by IL-2, which depends on the IL- $2 \mathrm{R} \alpha \beta \gamma_{\mathrm{c}}$ receptor, as in $\theta$.

\subsection{D: The $\mathrm{CDB}^{+} \mathrm{T}$-cell cytotoxicity parameter}

We have three patient-specific parameters in the model. These are $d, l$ and $s$, the parameters in $D$; they are some of the few parameters from de Pillis et al. that vary between patients 9 and 10. Simulations also show that the model is highly sensitive to the value of all three parameters. We therefore choose not to specify $d, l$ and $s$ and instead vary them as we run our simulations.

\section{Results}

In our simulations, we vary the initial tumour size, but keep all other initial state values fixed at the large-tumour equilibrium (9) values derived in Section 3.1. We restate them here as our initial conditions:

$$
N_{0}=2.5 \times 10^{8}, \quad L_{0}=5.268 \times 10^{5}, \quad C=2.25 \times 10^{9}, \quad M_{0}=0, \quad I_{0}=1073 .
$$

We also constructed a basic treatment protocol for each of $v_{L}, v_{M}$ and $v_{I}$ and ran ODE simulations with varying initial tumour sizes and combinations of treatments.

For chemotherapy, we follow the recommended dosage suggested by the manufacturers of the drug Adria (doxorubicin $\mathrm{HCl}$ [43]). The suggested procedure entails a single dose of $60-75 \mathrm{mg} / \mathrm{m}^{2}$ once every 21 days. We approximate an average human male to have surface area of $1.9 \mathrm{~m}^{2}$, as given in Ref. [31], and we use the upper end of the dosing range to arrive at $142.5 \mathrm{mg}$ doxorubicin every 21 days. Note that we model each half-hour infusion by setting $v_{M}$ to be constant and elevated for a full day. According to Ref. [22], doxorubicin has an extremely rapid distribution half-life and exits the bloodstream within minutes. Thus to get the concentration in the bloodstream (and in fact in all tissues, assuming uniform distribution), we use the figure of 59.71 average body volume for a man from Table 1 in Sendroy et al. [45] to get $v_{M}=2.3869 \mathrm{mg} / \mathrm{l}$ per day.

Dudley et al. [15] in their Table 1 compile a set of T-cell dosing protocols for individual patients. The number of $\mathrm{CD}^{+} \mathrm{T}$ cells injected into each patient ranges from $2.2 \times 10^{10}$ to $12.2 \times 10^{10}$. The average of the values in Dudley's Table 1 is $7.8 \times 10^{10}$ $\mathrm{CD} 8^{+} \mathrm{T}$ cells per day. To convert the value from an absolute population to a resulting blood concentration, we divide by 4.41 and set $v_{L}=1.77 \times 10^{10} \mathrm{CD} 8^{+} \mathrm{T}$ cells/l per day given once [6]. We model the single infusion by increasing $v_{L}$ to this value for a day.

Also in Dudley's Table 1 [15], the authors note that they inject $7.2 \times 10^{5} \mathrm{IU} / \mathrm{kg} \mathrm{IL}-2$ every $8 \mathrm{~h}$ ( 0.33 days) after the T-cell infusion for an average of 9 total IL-2 treatments. However, according to Ref. [26], IL-2 also has a very rapid distribution half-life. Consequently, as with $v_{M}$, we assume uniform distribution over all tissues. Using the average adult male human weight of $77 \mathrm{~kg}$ and again assuming 59.71 of body volume, 
we model this dosing regimen as $2.7859 \times 10^{6} \mathrm{IU}$ IL-2/1 per day for three days, spread evenly over the course of each day $[40,48]$. Note that immunotherapy refers to the combination of $\mathrm{CD}^{+} \mathrm{T}$-cell infusion with the above IL-2 treatment.

Only the $\mathrm{CD} 8^{+} \mathrm{T}$-cell infusion treatment need be modified, and we simply convert it from an absolute population to a resulting blood concentration by again dividing by 4.41 [6]. We obtain:

$$
v_{L}=1.77 \times 10^{10}, \quad v_{M}=2.3869, \quad v_{I}=2.7859 \times 10^{6} .
$$

Because we have three highly patient-specific parameters, as noted in Section 3.8, we separate our results for patient 9 and patient 10 from de Pillis et al. [12]. Note, however, that because the de Pillis et al. [12] model uses the total population of $L$ as opposed to the blood concentration, we must divide s by $V^{l}$, where $V=4.41$ is again the average human blood volume [6]. The results are stated below:

\begin{tabular}{cccc}
\hline & $d$ & $l$ & $s$ \\
\hline Patient 9 & 2.34 & 2.09 & $3.8 \times 10^{-3}$ \\
Patient 10 & 1.88 & 1.81 & $3.5 \times 10^{-2}$, \\
\hline
\end{tabular}

We ran all simulations for 200 days, as it was experimentally determined that all populations either reached equilibrium or became stably periodic within this time period. The results with a variety of initial tumour sizes are compiled in Table 4.

We may interpret the parameters $d, l$ and $s$ loosely as the strength or efficiency of the patient's immune system; these parameters correspond to the efficacy at which $\mathrm{CD}^{+} \mathrm{T}$ cells kill cancer cells. We then see from our Table 4 that patient 10 has a weaker immune system than patient 9 . Indeed, the results of pure chemotherapy are essentially identical between the 2 patients, but the success of immunotherapy and mixed treatment are superior in patient 9. This is to be expected, as a patient with more efficient immunetumour dynamics would be expected to benefit more from a boost to the immune system. This may suggest that an assessment of innate immune strength is in order before determining a treatment course; patients with low $\mathrm{CD} 8^{+} \mathrm{T}$-cell efficacy may not benefit from immunotherapy and might be optimally placed on chemotherapy alone, whereas other patients might benefit enormously from combined therapy.

We highlight a few simulations of particular interest. Figure 1 shows the results of our model with no therapy and an initial tumour size of $T_{0}=1 \times 10^{7}$ cells. The immune system is not able to kill the tumour unaided and the tumour grows to its large-tumour equilibrium value. $\mathrm{CD}^{+} \mathrm{T}$ cells and $\mathrm{NK}$ cells remain stable at their expected equilibrium values from (9). Similarly, as intended with the introduction of endogenous IL-2 synthesis, serum IL-2 ultimately remains at its expected equilibrium value.

In Figure 2, we keep the initial tumour size at $T_{0}=1 \times 10^{7}$ cells and initiate chemotherapy; the tumour is rapidly destroyed. This is a reasonable outcome with chemotherapy treatment on a relatively small tumour.

Finally, Figure 3 shows the results of combined therapy on a tumour of initial size $T_{0}=1 \times 10^{8}$ cells. The tumour is eliminated under these conditions. We see only a slight reduction in activated $\mathrm{CD} 8^{+} \mathrm{T}$ and NK cells concentrations as expected [23].

The numerics provide strong evidence that this system with these parameter values has at least two stable equilibrium points: one stable zero tumour equilibrium, and one stable large tumour equilibrium. Further analysis would be needed to confirm this, as well as to determine how the number and stability properties of the equilibrium points are affected by parameter changes. 


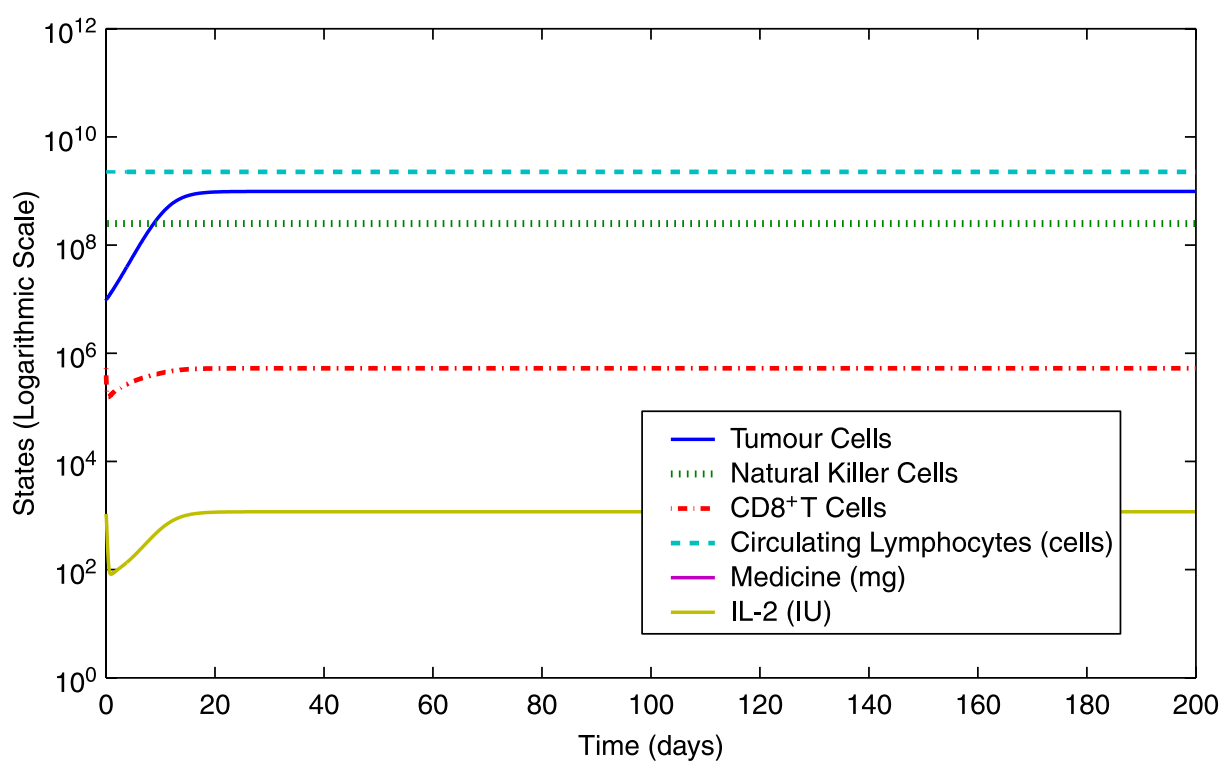

Figure 1. Model simulation: $T_{0}=1 \times 10^{7}$ cells, simulation with initial conditions (10) and $T_{0}=1 \times 10^{7}$ cells. The patient's unaided immune system is not able to destroy the tumour. No changes in circulating lymphocyte or NK cell concentrations are seen, as expected.

\section{Numerical sensitivity analysis}

A numerical parameter sensitivity analysis can highlight those model parameters that have the greatest effect on model outcome. A standard approach to performing this analysis is to fix all parameter values but one, and then to increase and decrease that one parameter by a certain

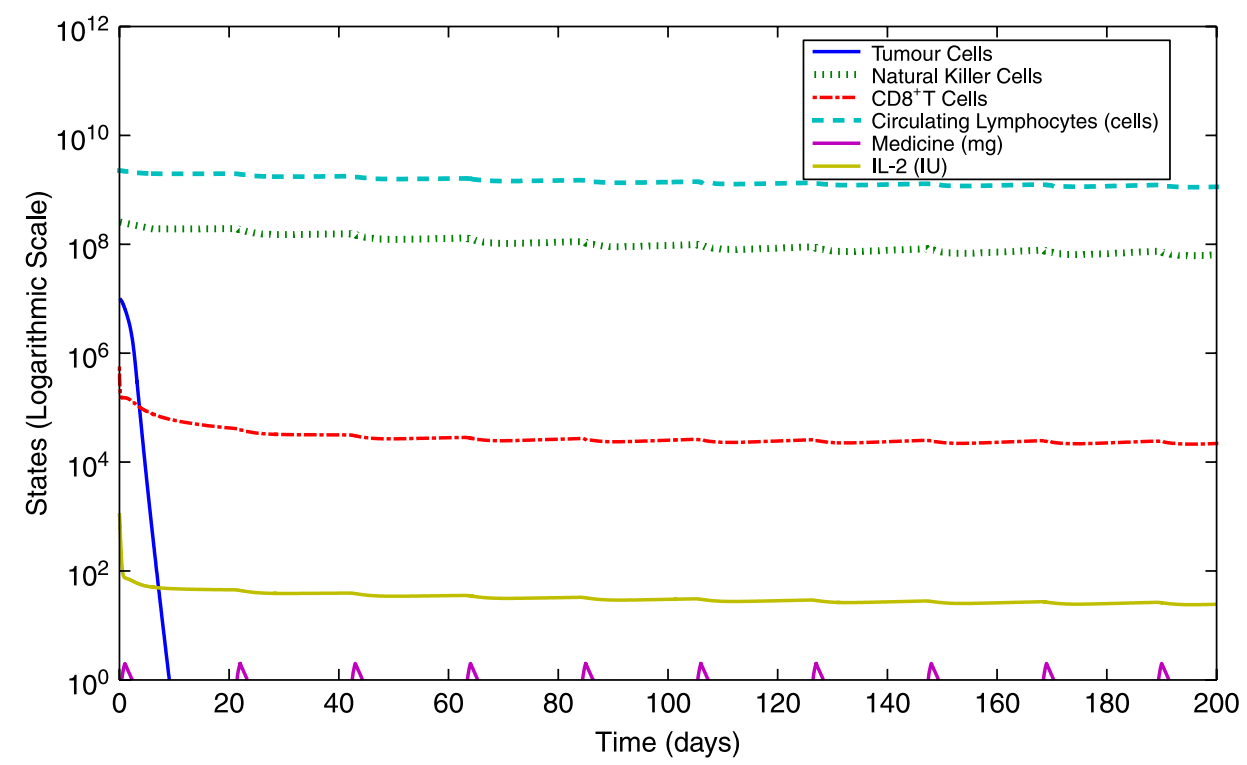

Figure 2. Model simulation $T_{0}=1 \times 10^{7}$ cells with chemotherapy, simulation with initial conditions (10), chemotherapy treatment (11) and $T_{0}=1 \times 10^{7}$ cells. Adding chemotherapy successfully kills the tumour, as expected for a relatively small initial tumour size. 


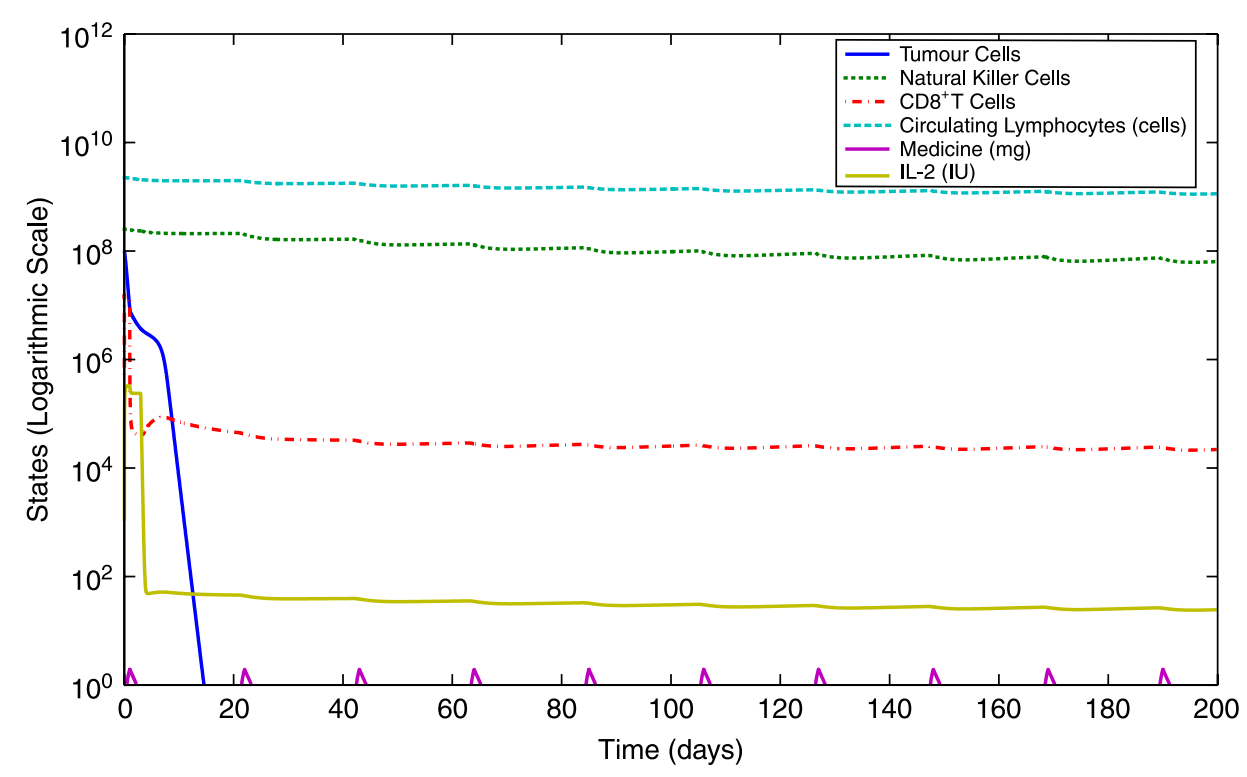

Figure 3. Model simulation $T_{0}=1 \times 10^{8}$ cells with chemotherapy and immunotherapy, simulation with initial conditions (10), chemotherapy and immunotherapy treatment (11) and $T_{0}=1 \times 10^{8}$ cells. The tumour is rapidly eliminated. Activated $\mathrm{CD}^{+} \mathrm{T}$ and NK cells drop slightly but still in agreement with [23].

Parameters Changed by 25 percent

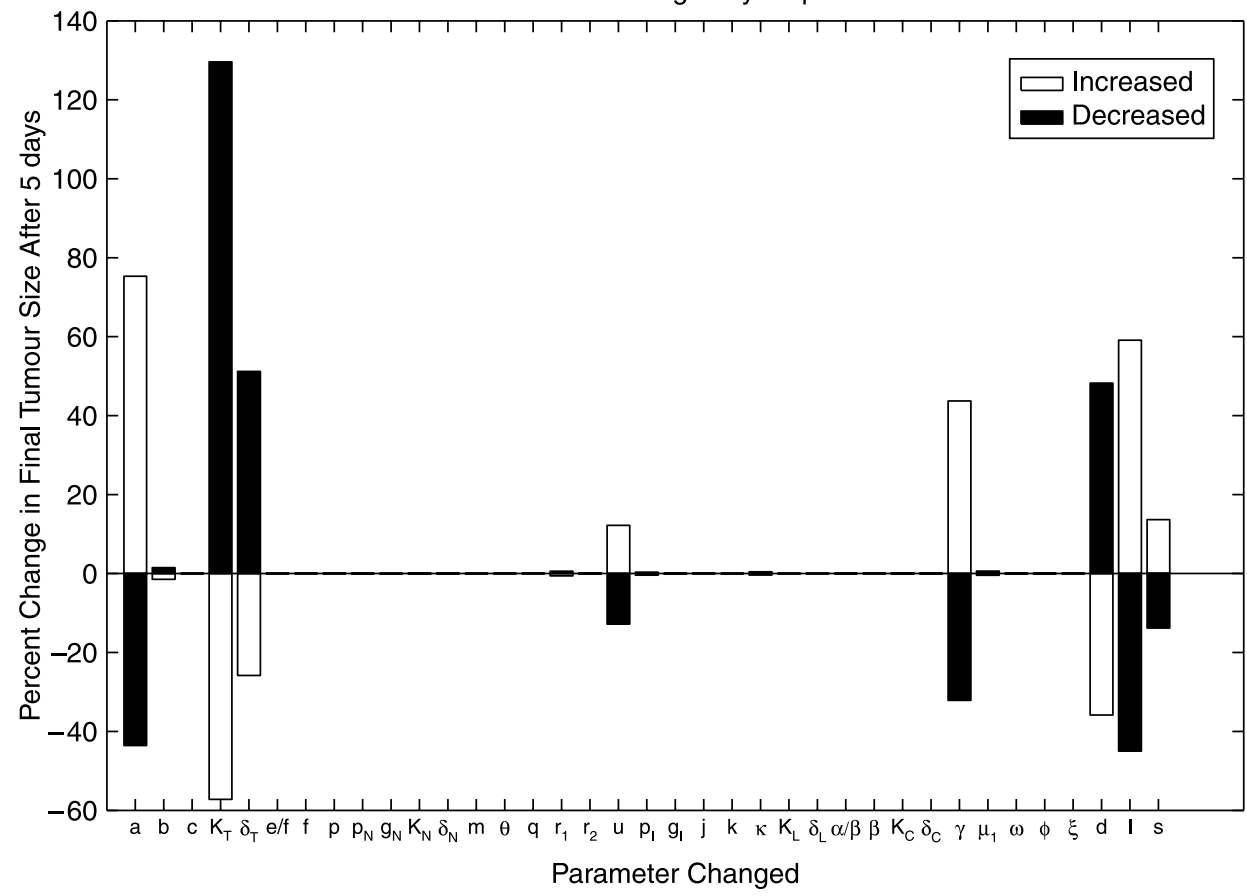

Figure 4. Numerical sensitivity analysis. Depicted is the effect of a $25 \%$ parameter change on final tumour size after 10 days. Initial conditions are as in Equation (10), with initial number of tumour cells $T_{0}=1 \times 10^{8}$. Patient 10 parameters were used. 
percentage, and examine the effect on the model endpoints. In Figure 4, we plot the percent change in tumour size from day zero to day five as a result of changing each of the model parameters by $25 \%$ in both directions. The fixed parameter values are taken from Table 3.

We note that although the model does have a relatively large number of parameters, it is clear that the model is significantly more sensitive to the changes in a few parameters than to the remaining parameters. It is not surprising, for example, that final tumour size is highly sensitive to the intrinsic tumour growth rate $a$ and to the strength of the chemotherapy action against the tumour, as represented by $K_{T}$ and $\delta_{T}$. The model is sensitive to $u$ since $\mathrm{CD}^{+} \mathrm{T}$ cells are the primary killers of tumour cells other than chemotherapy. Modifying $u$ dramatically changes how many $\mathrm{CD} 8^{+} \mathrm{T}$ cells are created due to IL-2 in a short period of time. Parameter $\gamma$ represents the rate of decay of the chemotherapy drug in the system. We therefore see sensitivity to $\gamma$, since this is related to the length of time the chemotherapy has to act against the tumour. We also see significant sensitivity to the values of $d, l$ and $s$. These parameters are all related to the effectiveness of the $\mathrm{CD}^{+} \mathrm{T}$ cells in stemming the growth of the tumour. Interestingly, it may be theoretically possible to determine these parameters through fits to patient-specific assay data, as was done in de Pillis et al. [13].

\section{Discussion}

We have updated the de Pillis et al. model [12] by incorporating the latest research on baseline NK and activated $\mathrm{CD} 8^{+} \mathrm{T}$-cell concentrations in both healthy donors and cancer patients. We have also included endogenous IL-2 production, added IL-2-stimulated NK cell proliferation and refined the IL-2-dependent regulation of activated $\mathrm{CD} 8^{+} \mathrm{T}$ cells. The results of our model align with recent data measuring baseline blood concentrations of several immune populations and, in particular, of IL-2. Moreover, we have carefully updated several parameter values with data from in vivo and in vitro research on turnover rates and mass-action kill rates. For the remaining parameters, we solved for the needed values using numerical equilibrium point information.

The results obtained from patients with different degrees of $\mathrm{CD} 8^{+} \mathrm{T}$-cell efficacy display insight into the potential success of immunotherapy. If individual $\mathrm{CD} 8^{+} \mathrm{T}$-cell tumour lysis data can be obtained, it may be possible to determine the potential use of immunotherapy as an adjunct to chemotherapy. Our updated model indicates that the more effectively $\mathrm{CD}^{+} \mathrm{T}$ cells taken from peripheral blood kill tumour cells, the more useful immunotherapy may be in conjunction with chemotherapy. Conversely, in patients with low immune efficacy, immunotherapy may be of relatively little help in eliminating cancerous tissue, as was seen in patient 10 from de Pillis et al. [12].

Further extensions to our model may be possible when more data become available on mass-action kill rates of NK and tumour antigen-specific $\mathrm{CD}^{+} \mathrm{T}$ cells, as well as when more precise estimates of immune cell recruitment rates can be obtained. Moreover, a next step may be to further fractionate the circulating lymphocytes and track the helper or memory $\mathrm{CD} 4{ }^{+} \mathrm{T}$-cell and dendritic cell populations, as both are intricately involved in activation and synthesis of $\mathrm{CD}^{+} \mathrm{T}$ cells.

\section{Acknowledgements}

This work was supported in part by generous funding from the W. M. Keck Foundation through the Harvey Mudd College Center for Quantitative Life Sciences as well as by the National Science Foundation Grant Number DMS-0414011, 'Mathematical Modeling of the Chemotherapy, Immunotherapy and Vaccine Therapy of Cancer' for the students and Professors de Pillis, Gu and 
Fister. Any opinions, findings and conclusions or recommendations expressed in this material are those of the authors and do not necessarily reflect the views of the National Science Foundation.

\section{Note}

1. This work was supported by the National Science Foundation under grant NSF-DMS-041-4011.

\section{References}

[1] A.K. Abbas and A.H. Lichtman, Cellular and Molecular Immunology, 5th ed., Elsevier Saunders, St. Louis, MO, 2005.

[2] J.A. Adam and N. Bellomo, Survey of Models for Tumor-Immune System Dynamics, Birkhauser, Boston, 1997.

[3] J.C. Arciero, T.L. Jackson, and D.E. Kirschner, Mathematical model of tumor-immune evasion and siRNA treatment, Discrete Contin. Dyn. Syst. Ser. B 4 (2004), pp. 39-58.

[4] B. Asquith, C. Debacq, A. Florins, N. Gillet, T. Sanchez-Alcaraz, A. Mosley, and L. Willems, Quantifying lymphocyte kinetics in vivo using carboxyflourescein diacetate succinimidyl ester (CFSE), Proc. R. Soc. B 273 (2006), pp. 1165-1171.

[5] D. Avigan, Dendritic cells: Development, function and potiental use for cancer immunotherapy, Blood Rev. 13 (1999), pp. 51-64.

[6] J.R. Cameron, J.G. Skofronick, and R.M. Grant, Physics of the Body, Medical Physics Publishing, Madison, WI, 1999.

[7] M. Chaplain and A. Matzavinos, Mathematical modeling of spatio-temporal phenomena in tumour immunology, Tutor. Math. Biosci. III (2006), pp. 131-183.

[8] R.J. De Boer, P. Hogeweg, H.F.J. Dullens, R.A. De Weger, and W. DenOtter, Macrophage t lymphocyte interactions in the anti-tumor immune response: A mathematical model, J. Immunol. 134 (1985), pp. 2748-2758.

[9] R.J. De Boer, H. Mohri, D.D. Ho, and A.S. Perelson, Turnover rates of B cells, T cells, and NK cells in simian immunodeficiency virus-infected and uninfected rhesus macaques, J. Immunol. 170 (2003), pp. 2479-2487.

[10] S. De Lillo, M.C. Salvatori, and N. Bellomo, Mathematical tools of the kinetic theory of active particles with some reasoning on the modelling progression and heterogeneity, Math. Comput. Model. 45 (2007), pp. 564-578.

[11] A. d'Onofrio, Tumor evasion from immune control: Strategies of a miss to become a mass, Chaos Solitons Fractals 31 (2007), pp. 261-268.

[12] L.G. de Pillis, W. Gu, and A.E. Radunskaya, Mixed immunotherapy and chemotherapy of tumors: Modeling, applications, and biological interpretations, J. Theor. Biol. 238 (2006), pp. 841-862.

[13] L.G. de Pillis, A.E. Radunskaya, and C.L. Wiseman, A validated mathematical model of cellmediated immune response to tumor growth, Cancer Res. 65 (2005), pp. 7950-7958.

[14] A. Diefenbach, E.R. Jensen, A.M. Jamieson, and D.H. Raulet, Rael and H60 ligands of the NKG2D receptor stimulate tumor immunity, Nature 413 (2001), pp. 165-171.

[15] M.E. Dudley et al., Cancer regression and autoimmunity in patients after clonal repopulation with antitumor lymphocytes, Science 298 (2002), pp. 850-854.

[16] J. Dunne, S. Lynch, C. O'Farrelly, S. Todryk, J.E. Hegarty, C. Feighery, and D.G. Doherty, Selective expansion and partial activation of human NK cells and NK receptor-positive T cells by IL-2 and IL-15, J. Immunol. 167 (2001), pp. 3129-3138.

[17] E.J. Freireich, E.A. Gehan, D.P. Rall, L.H. Schmidt, and H.E. Skipper, Quantitative comparison of toxicity of anticancer agents in mouse, rat, hamster, dog, monkey and man, Cancer Chemother. Rep. 50 (1966), pp. 219-244.

[18] S.N. Gardner, A mechanistic, predictive model of dose-response curves for cell cycle and phase-specific and-nonspecific drugs, Cancer Res. 60 (2000), pp. 1417-1425.

[19] J.F. Gillooly, J.H. Brown, G.B. West, V.M. Savage, and E.L. Charnov, Effects of size and temperature on metabolic rate, Science 293 (2001), pp. 2248-2251.

[20] M. Hellerstein et al., Directly measured kinetics of circulating T lymphocytes in normal and HIV-1-infected humans, Nat. Med. 5 (1999), pp. 83-89.

[21] C.A. Janeway, P. Travers, Jr., M. Walport, and M.J. Sclomchik, Immunobiology, Garland Science Publishing, London, 2005. 
[22] M. Joerger, A.D.R. Huitema, P.L. Meenhorst, J.H.M. Schellens, and J.H. Beijnen, Pharmacokinetics of low-dose doxorubicin and metabolites in patients with AIDS-related kaposi sarcoma, Cancer Chemother. Pharmacol. 55 (2005), pp. 488-496.

[23] V. Jurisitc, G. Konevic, O. Markovic, and M. Colovic, Clinic stage-depending decrease of NK cell activity in multiple myeloma patients, Med. Oncol. 24 (2007), pp. 312-317.

[24] D. Kirschner and J.C. Panetta, Modeling immunotherapy of the tumor-immune interaction, J. Math. Biol. 37 (1998), pp. 235-252.

[25] G. Konjevic and I. Spuzic, Stage dependence of NK cell activity and its modulation by interleukin 2 in patients with breast cancer, Neoplasma 40 (1993), pp. 81-85.

[26] M.W. Konrad, G. Hemstreet, E.M. Hersh, P.W. Mansell, R. Mertelsmann, J.E. Kolitz, and E.C. Bradley, Pharmacokinetics of recombinant interleukin 2 in humans, Cancer Res. 50 (1990), pp. 2009-2017.

[27] V.A. Kuznetsov, I.A. Makalkin, M.A. Taylor, and A.S. Perelson, Nonlinear dynamics of immunogenic tumors: Parameter estimation and global bifurcation analysis, Bull. Math. Biol. 56 (1994), pp. 295-321.

[28] P.P. Lee et al., Characterization of circulating T cells specific for tumor-associated antigens in melanoma patients, Nat. Med. 5 (1999), pp. 677-685.

[29] D.G. Mallet and L.G. De Pillis, A cellular automata model of tumor-immune system interactions, J. Theor. Biol. 239 (2006), pp. 334-350.

[30] N.J. Meropol, G.M. Barresi, T.A. Fehniger, J. Hitt, M. Franklin, and M.A. Galigiuri, Evaluation of natural killer cell expansion and activation in vivo with daily subcutaneous lowdose interleukin-2 plus periodic intermediate-dose pulsing, Cancer Immunol. Immunother. 46 (1998), pp. 318S-326S.

[31] R.D. Mosteller, Simplified calculation of body-surface area, N. Engl. J. Med. 317 (1987), p. 1098.

[32] B. Nelson, Il-2, regulatory T-cells, and tolerance, J. Immunol. 172 (2004), pp. 3983-3988.

[33] Novartis Pharmaceuticals Proleukin (aldesleukin): Pharmacology and indications, January 2007. http://www.proleukin.com/hcp/tools/pi-pharmacology.jsp

[34] A.S. Novozhilov, F.S. Berezovskaya, E.V. Koonin, and G.P. Karev, Mathematical modeling of tumor therapy with oncolytic viruses: Regimes with complete tumor elimination within the framework of deterministic models, Biol. Direct 1(6) (2006), pp. 1-18.

[35] M. Orditura, C. Romano, F. De Vita, G. Galizia, E. Lieto, S. Infusino, G. De Cataldis, and G. Catalano, Behaviour of interleukin-2 serum levels in advanced non-small-cell lung cancer patients: Relationship with response to therapy and survival, Cancer Immunol. Immunother. 49 (2000), pp. 530-536.

[36] M.R. Owen, H.M. Byrne, and C.E. Lewis, Mathematical modelling of the use of macrophages as vehicles for drug delivery to hypoxic tumour sites, J. Theor. Biol. 226 (2004), pp. 377-391.

[37] M.C. Perry, The Chemotherapy Source Book, 3rd ed., Lippincott Williams and Wilkins, Philadelphia, PA, 2001.

[38] B. Piccoli and F. Castiglione, Optimal vaccine scheduling in cancer immunotherapy, Phys. A 370 (2006), pp. 672-680.

[39] M.J. Pittet, D. Valmori, P.R. Dunbar, D.E. Speiser, D. Liénard, F. Lejeune, K. Fleischhauer, V. Cerundolo, J.C. Cerottini, and P. Romero, High frequencies of naive melan-a/MART-1specific $C D 8+T$ cells in a large proportion of human histocompatibility leukocyte antigen (HLA)-A2 individuals, J. Exp. Med. 190 (1999), pp. 705-715.

[40] A. Raman, R.J. Colman, Y. Cheng, J.W. Kemnitz, S.T. Baum, R. Weindruch, and D.A. Schoeller, Reference body composition in adult rhesus monkeys: Glucoregulatory and anthropometric indices, J. Gerontol. 60A (2005), pp. 1518-1524.

[41] Y. Refaeli, L.V. Parijs, C.A. London, J. Tschopp, and A. Abbas, Biochemical mechanisms of IL-2-regulated fas-mediated T cell apoptosis, Immunity 8 (1998), pp. 616-623.

[42] C. Ruedl, P. Koebel, M. Bachmann, M. Hess, and K. Karjalainen, Antatomical origin of dendritic cells determines their life span in peripheral lymph nodes, J. Immunol. 165 (2000), pp. 4910-4916.

[43] RxList Inc. Adria (doxorubicin hydrochloride) drug indications and dosage, January 2007. http://www.rxlist.com/cgi/generic/adriamycin_ids.htm

[44] G.K. Schwartz and E.S. Casper, A phase II trial of doxorubicin HCL liposome injection in patients with advanced pancreatic adenocarcinoma, Invest. New Drugs 13 (1995), pp. 77-82.

[45] J. Sendroy, Jr., and H.A. Collison, Determination of human body volume from height and weight, J. Appl. Physiol. 21 (1966), pp. 167-172. 
[46] D.E. Speiser et al., The activatory receptor 2B4 is expressed in vivo by human CD8 + effector alpha beta T cells, J. Immunol. 167 (2001), pp. 6165-6170.

[47] J. Wihlm, J.M. Limacher, D. Levegue, B. Duclos, P. Dufour, J.P. Bergerat, and G. Methlin, Phar-macokinetic profile of high-dose doxorubicin administered during a $6 \mathrm{~h}$ intravenous infusion in breast cancer patients, Bull. Cancer 84 (1997), pp. 603-608.

[48] D.F. Williamson, Descriptive epidemiology of body weight and weight change in US adults, Ann. Intern. Med. 119 (1993), pp. 646-649. 


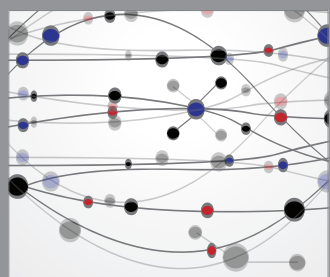

The Scientific World Journal
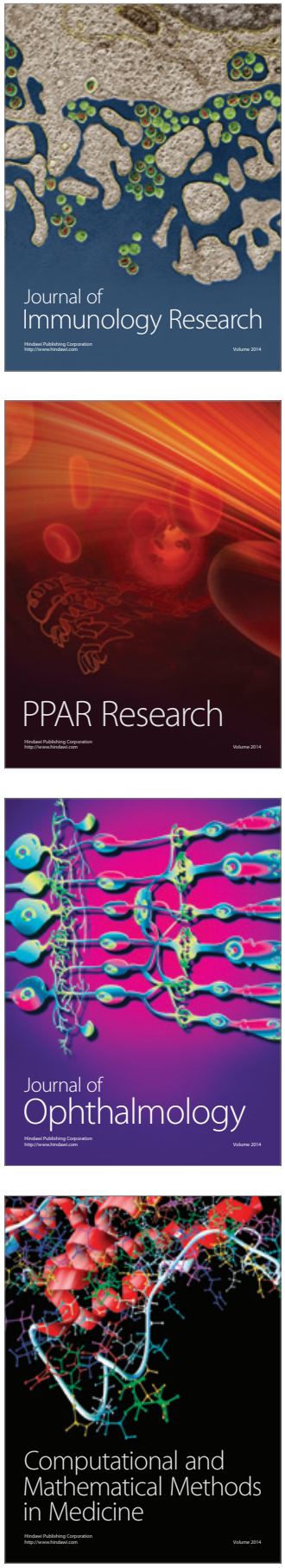

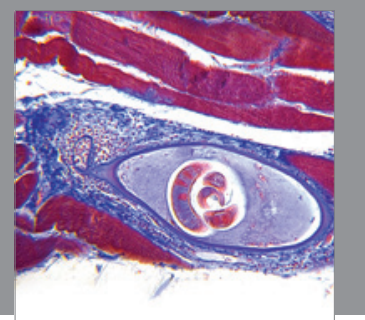

Gastroenterology

Research and Practice
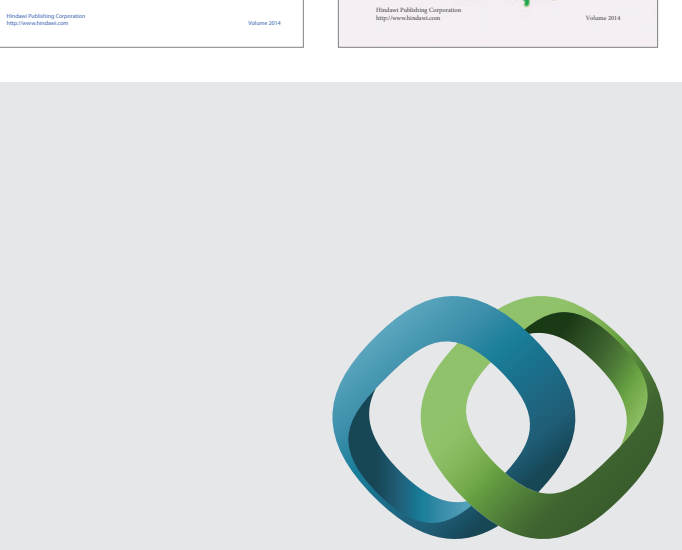

\section{Hindawi}

Submit your manuscripts at

http://www.hindawi.com
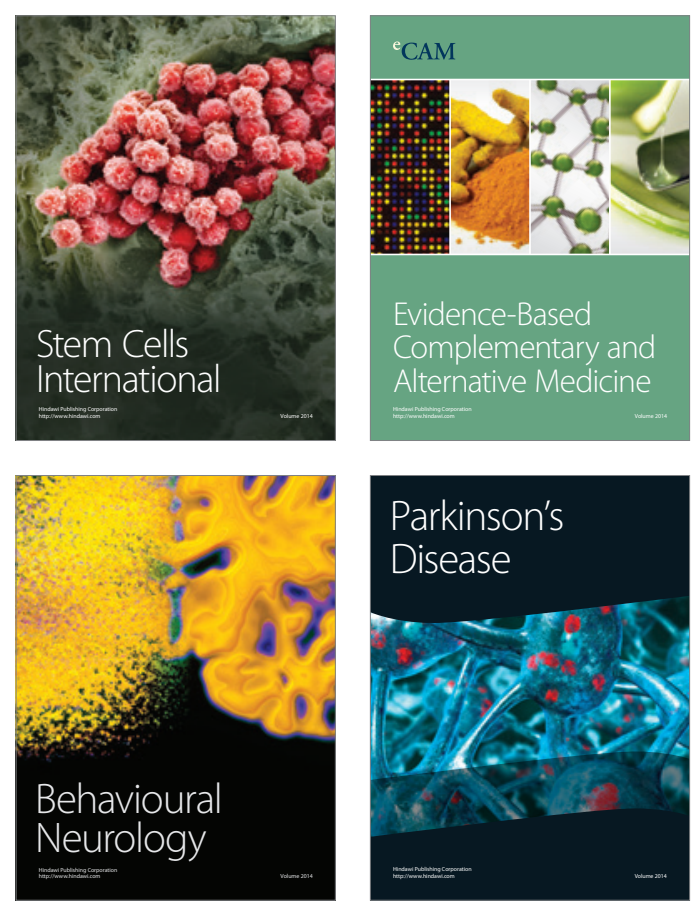

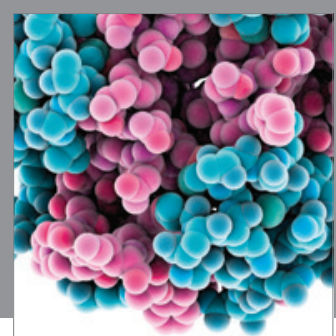

Journal of
Diabetes Research

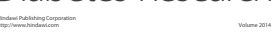

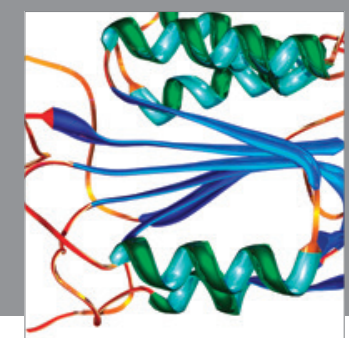

Disease Markers
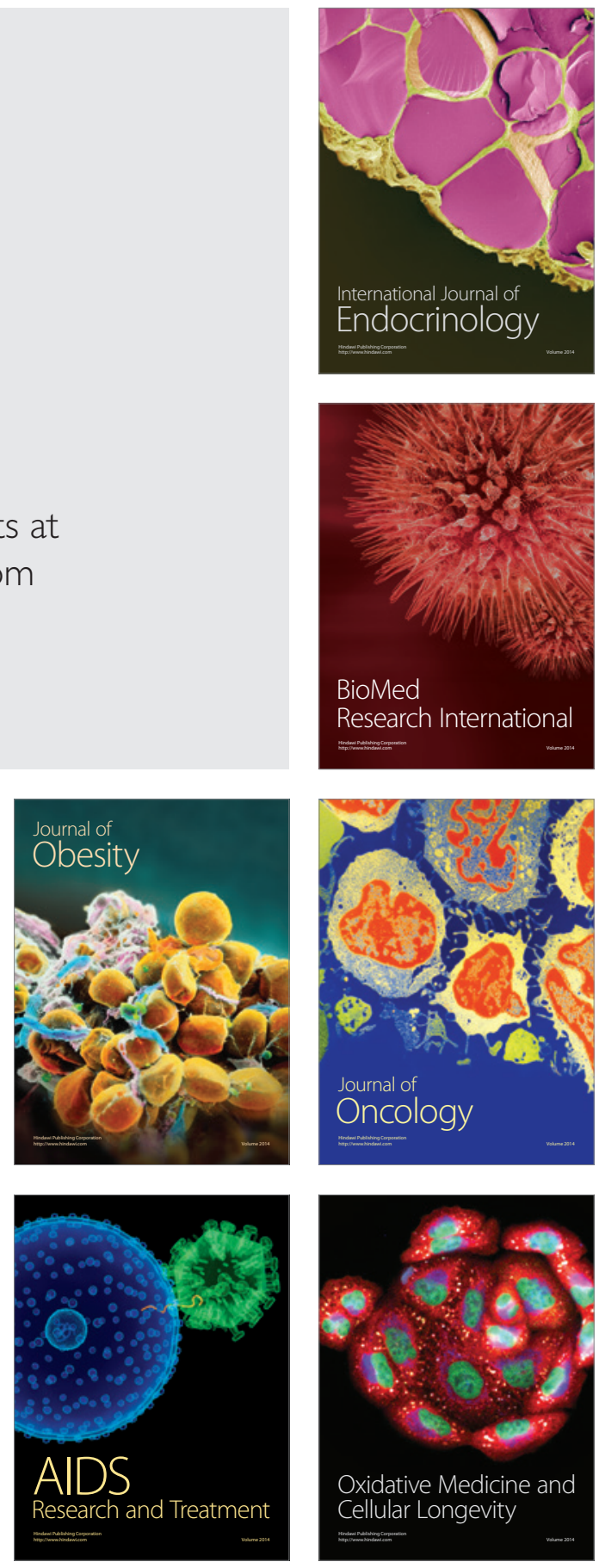